\title{
ANALISIS TINDAK TUTUR EKSPRESIF DALAM NOVEL HUJAN BULAN JUNI KARYA SAPARDI DJOKO DAMONO
}

\author{
${\text { Farah Fadhila Rahmadhani }{ }^{1} \text {, Asep Purwo Yudi Utomo }}^{2}$ \\ ${ }^{1}$ Universitas Negeri Semarang, Gedung B1 FBS UNNES, \\ farahfadhila2312@students.unnes.ac.id \\ ${ }^{2}$ Universitas Negeri Semarang, Gedung B1 Lantai 1 FBS UNNES, \\ aseppyu@mail.unnes.ac.id
}

\begin{abstract}
Expressive speech act is a type of speech act that functions to express the psychological attitude of the speaker towards a situation. For example, saying thank you, congratulating, apologizing, expressing condolences, threatening, praising, complaining, criticizing, and blaming. The author chooses expressive speech act research in the Hujan Bulan Juni novel because the stories of the characters are interesting and the research was still little done. The purpose of this study is to find out and recognize what expressive speech acts exist in the speech of the characters. The method used is descriptive qualitative. The data of this research are in the form of speeches by the characters in the novel. The technique used is the technique of reading and note taking. From 8 data, there are 3 speech acts of mocking, 2 speech acts of criticism, 2 speech acts of praise, and 1 speech act of complaining. From this research, it is expected to be used as a reference for expressive speech act learning. As well as adding insight into the meaning of speech in the novel that is useful in everyday life.
\end{abstract}

Keyword(s) : Pragmatic, speech act, expressive speech act, novel, Hujan Bulan Juni

\begin{abstract}
ABSTRAK
Tindak tutur ekspresif merupakan salah satu jenis tindak tutur yang berfungsi untuk mengungkapkan sikap psikologis penutur terhadap suatu keadaan. Misalnya, mengucapkan terima kasih, mengucapkan selamat, memberi maaf, mengucapkan belasungkawa, mengancam, memuji, mengeluh, mengkritik, dan menyalahkan. Penulis memilih penelitian tindak tutur ekspresif pada novel Hujan Bulan Juni karena cerita tokoh-tokohnya yang menarik dan penelitian tersebut masih sedikit dilakukan. Tujuan penelitian ini yaitu untuk mengetahui dan mengenal tindak tutur ekspresif apa saja yang ada pada tuturan para tokoh. Metode yang digunakan yaitu deskriptif kualitatif. Data penelitian ini berupa tuturan para tokoh yang ada pada novel tersebut. Teknik yang digunakan yaitu teknik baca dan catat. Dari 8 data, terdapat 3 tindak tutur ekspresif mengejek, 2 tindak tutur ekspresif mengkritik, 2 tindak tutur ekspresif memuji, dan 1 tindak tutur ekspresif mengeluh. Dari penelitian ini diharapkan dapat dijadikan
\end{abstract}


rujukan pembelajaran tindak tutur ekspresif. Sekaligus menambah wawasan tentang makna tuturan dalam novel yang berguna dalam kehidupan sehari-hari.

Kata Kunci : Pragmatik, tindak tutur, tindak tutur ekspresif, novel, Hujan Bulan Juni

How to Cite: Rahmadhani, Farah Fadhila \& Asep Purwo Yudi Utomo. (2020). Analisis Tindak Tutur Ekspresif dalam Novel Hujan Bulan Juni Karya Sapardi Djoko Damono. Bahtera Indonesia: Jurnal Penelitian Pendidikan Bahasa dan Sastra Indonesia, Vol. 5, No. 2, 88-96.

DOI: https://doi.org/10.31943/bi.v5i2.69

\section{PENDAHULUAN}

Salah satu studi linguistik yang merupakan bagian dari semiotik ialah pragmatik. Menurut Morris, pragmatik adalah cabang semiotik yang mempelajari relasi tanda dan penafsirannya (Levinson 1983:1). Sedangkan menurut Rustono (1999), pragmatik adalah bidang linguistik yang mengkaji hubungan timbal balik antara fungsi dan bentuk tuturan. Di dalam batasan yang sederhana itu, secara implisit tercakup penggunaan bahasa, komunikasi, konteks, penafsiran.

Pragmatik adalah satu di antara cabang ilmu bahasa yang masih tergolong baru bila dilihat dari perkembangannya. Pragmatik adalah studi kebahasaan yang terikat konteks. Konteks memiliki peranan kuat dalam menentukan maksud penutur dalam berinteraksi dengan lawan tutur (Rohmadi, 2010: 2).

Hal yang penting di dalam kajian pragmatik adalah tindak tutur, yaitu kegiatan melakukan tindakan mengujarkan tuturan kepada mitra tutur dengan maksud tertentu. Tindak tutur dibagi menjadi tiga, yaitu tindak tutur lokusi, tindak tutur ilokusi, dan tindak tutur perlokusi. Tindak tutur ilokusi merupakan tindak tutur yang mengandung maksud dan fungsi. Searle (dalam Rustono, 1999: 39) menggolongkan lima jenis tindak tutur ilokusi, yaitu representatif/asertif, direktif, komisif, ekspresif/evaluatif, deklaratif/isabati. Sejalan dengan pendapat tersebut, Chaer dan Agustina (2010: 29-30) membagi tindak tutur ilokusi menjadi lima kategori, yaitu deklaratif, refresentatif, ekspresif, direktif, dan komisif.

Hal yang menjadi fokus dari kajian ini ialah tindak tutur ekspresif, merupakan ilokusi yang berfungsi untuk mengungkapkan sikap psikologis penutur terhadap keadaan yang tersirat dalam ilokusi. Misalnya, mengucapkan terima kasih, mengucapkan selamat, memberi maaf, megucapkan belasungkawa, mengancam, memuji, 
mengeluh, mengkritik, dan menyalahkan. Tindak tutur ekspresif adalah tindak tutur yang menyatakan sesuatu yang dirasakan oleh penutur (Yule, 2006:93).

Novel Hujan Bulan Juni karya Sapardi Djoko Damono menjadi pilihan Penulis untuk diteliti tindak tutur ekspresifnya. Novel ini tentang perjalanan asmara Sarwono dengan Pingkan, keduanya memiliki sedikit banyak perbedaan. Kemudian, kajian tentang tindak tutur ekspresif pada novel Hujan Bulan Juni masih sedikit dilakukan. Oleh karena itu, Penulis menjadi tertarik meneliti novel tersebut.

Terdapat beberapa penelitian yang relevan dari penelitian ini, antara lain Nansi Avista, dkk (2018) yang mengkaji tindak tutur ilokusi percakapan antartokoh dalam novel Hujan Bulan Juni karya Sapardi Djoko

Damono. Sri Murti, dkk (2018) mengkaji tindak tutur ekspresif dalam film Kehormatan di Balik Kerudung sutradara Tya Subiakto Satrio. Lita Dwi Ariyanti dan Ida Zulaeha (2017) menganalisis tindak tutur ekspresif humanis dalam interaksi pembelajaran di SMA Negeri 1 Batang. Yenita Niken Larasati (2017) menganalisis tindak tutur ekspresif dalam nvel Hati Sinden karya Dwi Rahayuningsih dan relevansinya terhadap bahan ajar bahasa Indonesia materi drama di SMA. Fenda Dina Puspita Sari (2013) mengkaji tindak tutur dan fungsi tuturan ekspresif dalam acara "Galau Nite" di Metro TV. Rahmadi Fitra (2015) menganalisis tindak tutur ekspresif dalam novel Negeri 5 Menara karya Ahmad Fuadi. Redho Nurdiansyah, dkk (2019) mengkaji tindak tutur asertif dan ekspresif dalam novel Bumi karya Tere Liye. Fitri Ayu Astuti, dkk (2020) mendeskripsikan strategi tindak tutur penolakan dalam interaksi pedagang dan pembeli di Plaza Kebun Sayur Balikpapan. Lalu, Elsi Oktavianti (2015) mengkaji tindak tutur ekspresif dalam novel Burung Terbang di Kelam Malam karya Arafat Nur.

Dari beberapa penelitian tersebut, terdapat persamaan dan perbedaan dengan penelitian yang dilakukan. Persamaan yang banyak dijumpai yaitu penelitian terhadap tindak tutur terutama tindak tutur ekspresif, dan perbedaannya ada pada sumber data.

Penelitian ini bertujuan untuk mengetahui tindak tutur ekspresif apa saja yang ada pada percakapan antartokoh dalam novel Hujan Bulan Juni karya Sapardi Djoko Damono. Maka dari itu, Penulis memfokuskan penelitian pada "Analisis Tindak Tutur Ekspresif Dalam Novel Hujan Bulan Juni Karya Sapardi Djoko Damono.”

\section{METODOLOGI PENELITIAN}

Metode yang digunakan dalam penelitian ini adalah deskriptif kualitatif. Metode deskriptif pada penelitian ini digunakan untuk mengetahui gambaran dari 
tindak tutur ekspresif di dalam percakapan antartokoh pada novel Hujan Bulan Juni karya Sapardi Djoko Damono. Data yang dikumpulkan adalah berupa kata-kata, gambar, dan bukan angka-angka (Moleong, 2011: 11).

Penelitian tersebut merupakan penelitian kualitatif. Di mana data yang diperoleh berupa kata-kata atau kalimat yang menunjukkan tindak tutur ekspresif dalam novel Hujan Bulan Juni karya Sapardi Djoko Damono.

Dengan demikian, sumber data penelitian ini adalah novel berjudul Hujan Bulan Juni karya Sapardi Djoko Damono. Data penelitian ini berupa percakapan yang mengandung tindak tutur ekspresif yang dapat berupa tuturan mengucapkan terima kasih, mengucapkan selamat, memberi maaf, memuji, mengucapkan belasungkawa, mengancam, mengkritik, mengeluh, dan menyalahkan.

Teknik yang digunakan dalam pengambilan data adalah teknik baca dan teknik catat. Sebelum penelitian menggunakan teknik catat, peneliti membaca terlebih dahulu novel Hujan Bulan Juni karya Sapardi Djoko Damono untuk menemukan tuturan yang merupakan tindak tutur ekspresif. Kemudian menggunakan teknik catat untuk mendata tuturan yang termasuk tindak tutur ekspresif dengan memperhatikan konteks dalam tuturan.

\section{HASIL DAN PEMBAHASAN}

Analisis tindak tutur ekspresif dalam novel Hujan Bulan Juni karya Sapardi Djoko Damono ini melengkapi hasil penelitian terdahulu yang meneliti terkait tindak tutur ekspresif dalam novel. Penelitian ini terdapat kesamaan dengan penelitian sebelumnya yaitu rumusan masalah yang diteliti. Hasil penelitian ini ditemukan 8 data tindak tutur ekspresif yang dapat diklasifikasikan menjadi 3 tindak tutur ekspresif mengejek, 2 tindak tutur ekspresif mengkritik, 2 tindak tutur memuji, dan 1 tindak tutur ekspresif mengeluh.

\section{Tindak Tutur Ekspresif Mengejek}

Konteks: Pingkan mengejek Sarwono bahwa lelaki itu cengeng dan gombal ketika pertama kali membaca sajak yang dipamerkan oleh Sarwono.

Tuturan I: "Kamu ini cengeng, Sar, jualan gombal” (Hlm. 10/Bab 2)

Tuturan (I) merupakan hasil tindak tutur ekspresif jenis mengejek yang dituturkan oleh Pingkan kepada Sarwono. Pingkan menganggap Sarwono orang yang cengeng dan gombal ketika pertama kali dirinya membaca sajak di sebuah majalah yang dipamerkan oleh Sarwono. Tuturan (I) bertujuan untuk mengejek Sarwono, menggunakan alat ucap, dan termasuk ke dalam produk verbal karena terdapat tindakan berbicara atau bertutur. 
(2) Konteks: Sarwono berniat mengejek Pingkan dengan bertanya keberadaan tari di Menado untuk membuat jengkel Pingkan.

Tuturan II: "He, memang benar ada tari di Menado?" (Hlm. 35/Bab 2)

Tuturan (II) merupakan hasil tindak tutur ekspresif jenis mengejek yang dituturkan oleh Sarwono kepada Pingkan. Tuturan itu menyatakan bahwa Sarwono menggoda Pingkan dengan mempertanyakan keberadaan tari di Menado, yaitu kampung halaman Pingkan, untuk membuat gadis itu jengkel.

Konteks: Pingkan bertanya kepada

Sarwono sekaligus menertawainya tentang Sarwono yang tidak bisa menaiki Honda tanpa Mushashi.

Tuturan III: "Tanpa Mushashi, apa kamu bisa naik Honda? Hahaha." (Hlm. 52/Bab 2)

Tuturan (III) merupakan tindak tutur ekspresif jenis mengejek yang dituturkan oleh Pingkan kepada Sarwono. Tuturan tersebut menyatakan bahwa Pingkan bertanya sekaligus menertawai Sarwono tentang apakah tanpa Mushashi dia bisa naik Honda. Dalam narasinya, Pingkan selalu mengejek Sarwono karena ia masih menaiki sepeda motor kalau akan mengajar.

\section{Tindak Tutur Ekspresif Mengkritik}

(4) Konteks: Pingkan mengkritik Sarwono yang tidak maksud dengan penjelasan Pingkan tentang ronin. Padahal Sarwono sudah sekolah tinggi-tinggi namun otaknya melantai di bawah pohon sawo kecil.

Tuturan IV: "Sar, kamu ini sudah sekolah tinggi-tinggi tapi otakmu masih juga ngelosot di bawah pohon sawo kecil di halaman keraton itu." (Hlm. 13/Bab 2)

Tuturan (IV) merupakan tindak tutur ekspresif jenis mengkritik yang dituturkan dosen dari UI yang akan berangkat ke Jepang untuk belajar.oleh Pingkan kepada Sarwono. Tuturan tersebut menyatakan bahwa Sarwono tidak kunjung maksud dengan penjelasannya tentang ronin, padahal Sarwono orang yang sudah bersekolah sampai tinggi, namun otaknya melantai di bawah pohon sawo kecil. Tindak tutur ekspresif mengkritik digunakan Pingkan agar Sarwono berusaha memahami maksudnya.

Konteks: Pingkan menjawab pertanyaan Sarwono tentang Uniqlo, Pingkan mengkritik Sarwono dengan menyinggung Jawa Sarwono yang tidak hilang.

Tuturan V: "Wah, Jawamu gak lekang-lekang juga. Uniqlo aja gak tahu. Mau cari jaket sama syal, tau! 
April di Kyoto kan masih bisa menggigil.” (Hlm. 14/Bab 2)

Tuturan (V) merupakan hasil dari tindak tutur ekspresif jenis mengkritik yang dituturkan oleh Pingkan kepada Sarwono. Pingkan mengkritik Sarwono ketika pemuda itu menanyakan apa itu Uniqlo dengan menyinggung Jawa Sarwono yang tidak hilang. Tindak tutur ekspresif tersebut terjadi karena Sarwono yang tidak tahu mengenai Uniqlo.

\section{Tindak Tutur Ekspresif Memuji}

(6) Konteks: Seorang mahasiswa memuji Pingkan karena senang jika diajar

Tuturan VI: "Pinter dan tidak galak," katanya sambil mengacungkan dua jempolnya. (Hlm. 31/Bab 2)

Tuturan (VI) merupakan tindak tutur ekspresif jenis memuji yang dituturkan oleh seorang mahasiswa kepada Pingkan. Tuturan tersebut menyatakan bahwa Mahasiswa itu memuji Pingkan orang yang pintar dan tidak galak. Tindak tutur ekspresif tersebut terjadi karena penutur senang sekali dengan kehadiran dosen muda itu, sehingga keluarlah tuturan memuji. Tuturan tersebut juga memiliki tindakan yang dilakukan oleh penutur, yaitu mengacungkan dua jempol kepada mitra tutur.

(7) Konteks: Toar memuji hebat setelah melihat Sarwono dengan penuh semangat menceritakan petualangan akademiknya berada di beberapa daerah.

Tuturan VII: "Heibat, kau Sar." (Hlm. 107/Bab 2)

Tuturan (VII) merupakan hasil tindak tutur ekspresif memuji yang dituturkan oleh Toar kepada Sarwono. Pada tuturan tersebut, Toar mengucapkan kata hebat kepada Sarwono setelah diceritakan pengalaman akademiknya di berbagai daerah. Tuturan (VII) digunakan Toar untuk menyenangi hati Sarwono.

\section{Tindak Tutur Ekspresif Mengeluh}

(8) Konteks: Sarwono mengeluhkan susah membawa oleh-oleh yang banyak setelah Benny mengatakan akan ke Surabaya sebelum pulang ke Menado. Tuturan VIII: "Kan susah, ke manamana bawa oleh-oleh yang minta ampun banyaknya itu. " (Hlm. 82/Bab 2)

Tuturan (VIII) merupakan hasil tindak tutur ekspresif mengeluh yang dituturkan oleh Sarwono kepada Benny. Sarwono mengeluhkan rasa susah membawa oleh-oleh yang banyak sekali. Tuturan tersebut timbul karena tidak sesuai dengan yang diharapkan penutur.

Demikian hasil dari penelitian tindak tutur ekspresif pada novel Hujan Bulan Juni karya Sapardi Djoko Damono. Harapannya dengan 
adanya penelitian ini, dapat dijadikan rujukan pembelajaran tindak tutur ekspresif. Sekaligus menambah wawasan tentang makna tuturan dalam novel yang berguna dalam kehidupan sehari-hari.

\section{SIMPULAN}

Berdasarkan hasil penelitian dan pembahasan tentang tindak tutur ekspresif pada novel Hujan Bulan Juni, maka dapat disimpulkan bahwa pada penelitian ini ditemukan 8 data tindak tutur ekspresif yang meliputi: 3 tindak tutur ekspresif mengejek, 2 tindak tutur ekspresif mengkritik, 2 tindak tutur memuji, dan 1 tindak tutur ekspresif mengeluh. Tindak tutur ekspresif mengejek terdapat 3 data yang berkonteks: (1) Pingkan mengejek Sarwono karena cengeng dan gombal, (2) Sarwono mengejek Pingkan dengan bertanya adakah tari di kampungnya, dan (3) Pingkan menertawai Sarwono karena tidak bisa menaiki Honda tanpa Mushashi. Tindak tutur ekspresif mengkritik terdapat 2 data yang berkonteks: (1) Pingkan mengkritik Sarwono karena lambat berpikir padahal sudah sekolah tinggi-tinggi, dan (2) Pingkan mengkritik Sarwono yang bertanya tentang Uniqlo. Tindak tutur ekspresif memuji terdapat 2 data yang berkonteks: (1) Seorang mahasiswa memuji Pingkan karena akan berangkat ke Jepang untuk belajar, dan (2) Toar memuji Sarwono atas petualangan akademiknya. Tindak tutur ekspresif mengeluh terdapat 1 data yang berkonteks: Sarwono mengeluhkan susah membawa oleh-oleh. Dari data di atas maka tindak tutur ekspresif pada novel Hujan Bulan Juni karya Sapardi Djoko Damono yang paling banyak adalah tuturan mengejek dan yang paling sedikit adalah tuturan mengeluh.

\section{SARAN}

Adapun saran yang dapat penulis sampaikan, yaitu: tindak tutur ekspresif diharapkan dapat digunakan dalam interaksi kehiduapan sehari-hari, para peneliti dapat mengkaji lebih luas tentang tindak tutur ekspresif yang bermacam-macam, serta dapat pula meneliti tindak tutur ekspresif dalam novel lainnya, peneliti yang mengkaji tindak tutur ekspresif pada novel Hujan Bulan Juni karya Sapardi Djoko Damono belum bisa dikatakan sempurna, maka besar harapannya terhadap peneliti-peneliti baru untuk dapat meneliti novel tersebut secara lebih luas.

\section{DAFTAR PUSTAKA}

Ariyanti, Lita D., \& Zulaeha, I. (Agustus, 2017). Tindak Tutur Ekspresif Humanis dalam Interaksi Pembelajaran di SMA Negeri 1 Batang: Analisis Wacana Kelas. Seloka: Jurnal Pendidikan Bahasa dan Sastra Indonesia, 6(2), 111-122. URL:http://journal.unnes.ac.id/sju/in dex.php/seloka. Retrieved from https://journal.unnes.ac.id/sju/index. php/seloka/article/download/17272/8 $\underline{724 /}$ 
Avista, N., Sahrani, A., \& Sanulita, H. (September, 2018). Tindak Tutur Ilokusi Percakapan Antartokoh Dalam Novel Hujan Bulan Juni Karya Sapardi Djoko. Jurnal Pendidikan dan Pembelajaran Khatulistiwa, 7(9), 1-8. Retrieved from http://jurnal.untan.ac.id/index.php/jpdpb/ article/view/28539.

Ayu Astuti, F., Retnowaty, R., \& Maulida, N. (2020). Strategi Tindak Tutur Penolakan Dalam Interaksi Pedagang dan Pembeli di Plaza Kebun Sayur Balikpapan. Bahtera Indonesia; Jurnal Penelitian Bahasa DanSastra Indonesia, 5(1), 12-26. https://doi.org/10.31943/bi.v5i1.65

Chaer, Abdul dan Leonie Agustina. 2010. Sosiolinguistik Perkenalan Awal. Jakarta: Rineka Cipta.

Chamalah, E., \& Turahmat. (Maret, 2016). Tindak Tutur Ekspresif Pada Bak Truk Sebagai Alternatif Materi Ajar Pragmatik. Bahastra: Jurnal Universitas Ahmad Dahlan, 35(2), 27-40. Retrieved from http://journal.uad.ac.id/index.php/BAHA STRA/article/download/4859/2690

Fitra, Rahmadi. (2015). Tindak Tutur Ekspresif Dalam Novel Negeri 5 Menara Karya Ahmad Fuadi. Thesis. URL: http://scholar.unand.ac.id/id/eprint/1112

Laila, Siti A.N. (Jan, 2020). Tindak Tutur Ilokusi Pada Novel Yorick Karya Kirana Kejora dan Implikasinya Terhadap Pembelajaran Bahasa Indonesia di Madrasah Aliyah. URL: http://eprints.iainsurakarta.ac.id/id/eprint/4865

Larasati, Yenita N. (Oktober, 2017). Analisis Tindak Tutur Ekspresif Dalam Novel Hati Sinden Karya Dwi Rahayuningsih Kajian
Pragmatik dan Relevansinya Terhadap Bahan Ajar Bahasa Indonesia Materi Drama di SMA. Repository UPY URL: http://repository.upy.ac.id/id/eprint/1510. Retrieved fromhttp://repository.upy.ac.id/1510/1/A RTIKEL\%20YENITA\%20NIKEN\%20L ARASATI.pdf

Leech, Geoffrey. 1993. Prinsip-Prinsip Pragmatik (edisi terjemahan oleh M. D. D.Oka). Jakarta: Universitas Indonesia Press.

Levinson, C. Stephen. 1983. Pragmatics. Cambridge University Press.

Moleong, L. J. 2000. Metodologi Penelitian Kualitatif. Bandung: Remaja Rosda Karya.

Murti, Sri., Muslihah, Nur N., \& Sari, Intan P. (Juni, 2018). Tindak Tutur Ekspresif Dalam Film Kehormatan di Balik Kerudung Sutradara Tya Subiakto Satrio. Silampari Bisa: Jurnal Penelitian Pendidikan Bahasa Indonesia, Daerah, dan Asing, 1(1), 17-32. doi: 10.31540/silamparibisa.v1i1.7. Retrieved from

https://journal.unair.ac.id/SKRIP@tindak -tutur-dan-fungsi-tuturan-ekspresifdalam-acara-galau-nite-di-metro-tv-suatu-kajian-pragmatik-article-6651media-45-category-8.html

Nurdiansyah, R., Patriantoro \& Muzammil, A. R. (September, 2019). Tindak Tutur Asertif dan Ekspresif dalam Novel Bumi Karya Tere Liye. Jurnal Pendidikan dan Pembelajaran Khatulistiwa, 8(9), 1-9. Retrieved from http://jurnal.untan.ac.id/index.php/jpdpb/ article/view/35669/75676582951 
Oktavianti, E., Laila, A., \& Marni, S. Yusri. 2016. Ilmu Pragmatik dalam (November, 2015). Tindak Tutur Perspektif Kesopanan Berbahasa. Ekspresif Dalam Novel Burung Terbang Yogyakarta: Deepblish. di Kelam Malam Karya Arafat Nur. Retrieved from http://jim.stkip-pgrisumbar.ac.id/jurnal/download/4337

Rahardi, R. Kunjana. 2005. Pragmarik: Kesantunan Imperatif Bahasa Indonesia. Jakarta: Erlangga.

Riswanti. (2014). Analisis Tindak Tutur Direktif dan Ekspresif dalam Novel Kembang Saka Persi Karya Soebagijo I.N. Repository IAIN Surakarta. Retrieved from http://202.91.10.51:8080/xmlui/bitstream /handle/123456789/2369/112160759-

Riswanti.pdf? sequence $=1 \&$ is Allowed $=\mathrm{y}$

Rohmadi, Muhammad. 2010. Analisis Wacana Pragmatik. Surakarta: Yuma Pustaka.

Rustono. 1999. Pokok-Pokok Pragmatik. Semarang: CV. IKIP Semarang Press

Sari, Fenda D.P. (Maret, 2013). Tindak Tutur dan Fungsi Tuturan Ekspresif Dalam Acara Galau Nite di Metro TV: Suatu Kajian Pragmatik. Skriptorium, 1(2), 114.

Searle, John. R. 1981. Expression and Meaning Studies In The Theory Of Speech acts. New York (London): Cambrige University Press.

Tarigan, H. G. 2009. Pengajaran Pragmatik. Bandung: Angkasa Bandung.

Yule, George. 2014. Pragmatik. Jakarta: Pustaka Pelajar. 